\title{
Fighting for Child Custody When Domestic Violence Is at Issue: Survey of State Laws
}

\begin{abstract}
Amy Levin and Linda G. Mills
This study presents national data on each state's legislative approach to custody cases involving allegations of domestic violence. Battered women's advocates have successfully lobbied in some states for rebuttable presumption statutes that direct judges to deny sole or joint custody to abusive parents unless they present persuasive evidence establishing their suitability to obtain custody. Other states-at the behest of fathers' rights advocates - have adopted factor tests in which judges consider domestic violence as "one factor" in determining custody. Our findings suggest that each regulatory schema has strengths and weaknesses, but that these approaches have been developed without the benefit of intensive study.
\end{abstract}

Key words: battered women; best interests of the child; child custody; domestic violence; father's rights; social work practice

$\mathrm{F}$ Tamily law judges deciding child custody cases are often faced with difficult choices. Should a judge award joint custody to Jon and Lisa's father who has remarried a woman the children dislike? Should their mother, who has been the stable force in her children's lives, be the sole arbiter of the schools the children attend and the religious training they receive? Laws have emerged to help judges decide these heart-wrenching questions. In general, states have determined that the "best interests of the child" is the primary standard judges should apply in child custody cases. Although such a broad criterion allows for discretion, it can also invite judicial bias (Mills, 1999b).

One emerging concern in the area of child custody is how to temper judicial bias when domestic violence becomes an issue in a custody dispute. There is ample evidence that judges fail to take the violence seriously and award sole or joint custody to wife beaters (Liss \& Stahly, 1993; Pagelow, 1993; Zorza, 1995). Many judges believe that women either exaggerate men's violence or otherwise deliberately alienate their children from their fathers during divorce to gain a custody advantage (Gardner, 1992). Judges also are persuaded that fathers should be integrally involved in their children's lives after the divorce is final-regardless of the father's relationship with the children's mother.

Determining child custody in the context of domestic violence involves resolving an inherent tension between preserving and maintaining parent-child relationships and protecting children from emotional and physical harm. The best interests of the child standard attempts to reconcile this tension by directing judges to determine which parent better protects the child's safety and well-being. The laws are meant to focus on the child, not the parents. Protecting the safety of children as well as their mental and physical health poses a dilemma in cases where domestic violence is present. Judges struggle to decide 
whether a "battering" or a "victimized" parent can better fulfill the child's needs. Increasingly, judges must decide whether the violence of the father is more significant than the violence of the mother (Levin, 2000).

The literature on child custody and domestic violence suggests that the interests of the parents, not the children, are guiding custody decisions (Levin, 2000). Battered women's advocates argue on behalf of battered mothers that batterers should not be awarded custody of their children (Sun \& Thomas, 1987). They rely on the extensive literature that documents the detrimental psychological, emotional, and physical effects on children who witness violence. They argue that awarding custody to batterers perpetuates the intergenerational cycle of violence and further victimizes battered women by putting them in harms way. Fathers' rights advocates, on the other hand, emphasize the fathers' right to custody and rely on the growing literature documenting that children from divorced families benefit from significant involvement with both parents (Federico \& Kinscherff, 1996; Peled, 1996).

To explore further the practice implications of child custody determinations in cases involving domestic violence, this article presents national data documenting each state's legislative approach to child custody cases involving domestic violence. We found that 46 of 50 states and Washington, DC, have adopted one of two regulatory schemes for addressing a history of domestic violence when custody is at issue: (1) a rebuttable presumption standard or (2) a factor test approach. The remaining four states do not include considerations of domestic violence in their custody statutes. We frame this discussion in the larger debate between battered women's and father's rights advocates and suggest the limitations of each approach. We call for research in an effort to clarify which legislative approach most focuses on the children's needs and best protects the children and their victimized parent.

\section{Positioning Battered Women to Obtain Custody}

Professionals-social workers, attorneys, advocates-who support granting custody to battered women or preventing batterers from obtaining custody emphasize the detrimental psychological, physical, and emotional effects on children of witnessing violence between their parents. In a study by Hilton (1992), at least 70 percent of the battered women had children who had witnessed domestic violence. Researchers have found that children who witness adult-on-adult violence are at risk of psychological and emotional problems (Aron \& Olson, 1997; Cahn, 1991; Campbell \& Lewandowski, 1997; Fergusson \& Horwood, 1998; O'Keefe, 1994a, 1994b, 1995; Pagelow, 1990; Peled, 1996). More specifically, they can suffer from internalizing problems, such as anxiety, depression, and withdrawal (Campbell \& Lewandowski; Carlson, 1996; O’Keefe, 1994a, 1994b, 1995; Quirion, Lennett, Lund, \& Tuck, 1997) as well as externalizing problems, such as aggression, delinquency, and acting out (Carlson, 1996; O'Keefe, 1994a, 1994b, 1995).

Some researchers have found that boys tend to suffer more externalizing problems whereas girls tend to experience more internalizing problems (Pagelow, 1990). However, other studies have found no gender effects (O'Keefe, 1994a; Wolfe, Jaffe, Wilson, \& Zak, 1988). Children who witness domestic violence in their homes are at increased risk of impaired social competence (Carlson, 1996; O'Keefe, 1994a), posttraumatic stress disorder (Carlson; Johnson, 1998; Peled, 1996; Quirion et al., 1997), substance abuse (Roy, 1988), and suicide (Fergusson \& Horwood, 1998; Johnson; Quirion et al.). It is important to stress, however, that some children are resilient in the face of domestic violence. Wolfe and colleagues (1988) found that 26 percent of the children they studied remained well-adjusted despite the fact that they were living with abuse.

One important study of parents involved in custody disputes revealed that violence continued after the parents' separation. Johnston, Campbell, and Linda (1993) reported significant levels of abuse by both men and women who could not resolve their custody and visitation issues because of ongoing violence. They identified several parental profiles, including ongoing and episodic male battering, female-initiated violence, malecontrolling interactive violence, separating-engendered and postdivorce trauma, and psychotic and paranoid reactions. As might be predicted, the children's reactions to their parents' violence were significant. Ongoing male battering presented the most traumatizing experiences for boys and girls.

Battered women's advocates caution that there is a significant overlap between domestic violence 
and child abuse. It has been argued that in 40 percent to 70 percent of the cases where there is domestic violence in the home, the children are also abused (Edleson, 1998; Pagelow, 1990; Quirion et al., 1997). Ross (1996) found that the more a male batterer abuses his spouse, the greater the likelihood he also abuses his children. In addition, in Ross's community sample, the relationship between spousal abuse and child abuse was greater for husbands than for wives. Children who witness domestic violence and experience physical abuse tend to have more negative outcomes (Carlson, 1996; O'Keefe, 1995; Peled, 1996). Some argue that engaging in intimate abuse in front of children is itself a form of child abuse (In re Heather A., 1996).

There is some evidence of an intergenerational transmission of violence in families with domestic violence (Quirion et al., 1997; Wolfe et al., 1988). Children who witness domestic violence have an increased likelihood of becoming batterers (Cahn, 1991; Hotaling \& Sugarman, 1990; Quirion et al., 1997). They learn that violence is acceptable (Straus, 1995; Sun \& Thomas, 1987) and learn patterns of abusive behavior (Crites \& Coker, 1988; O'Keefe, 1995). In a study by Stark and Flitcraft (1985), however, the researchers found no evidence of the intergenerational transmission of violence. There is mixed data on whether girls who grow up in homes where there is domestic violence are likely to repeat the pattern in their adult relationships (Fantuzzo \& Lindquist, 1989).

\section{Positioning Batterers to Obtain Custody}

Fathers' rights advocates argue that fathers should have joint custody of their children after divorce and that fathers have been unfairly disadvantaged in decisions that tend to favor maternal custody (Fineman \& Opie, 1987). Most proponents of granting custody to fathers rely on studies that underscore the positive effects on children's wellbeing of maintaining contact with their fathers after separation (Coltrane, 1995; Federico \& Kinscherff, 1996; Peled, 1996; Thompson, 1983). Little, if any, research has been conducted on whether fathers should have custody of their children after separation, when the fathers have engaged in domestic violence against the children's mothers (Straus, 1995).

The literature on children's adaptations to divorce suggests that children benefit from contact with their fathers after divorce (Coltrane, 1995;
Federico \& Kinscherff, 1996; Peled, 1996; Thompson, 1983; Wallerstein \& Kelly, 1982). Boys, in particular, benefit from continuing contact with their fathers (Thompson, 1983). Children from violent homes, however, are confronted with a "double-edged sword." They both love and fear their abusive parent. Researchers suggest that given children's attachments to their fathers, it is beneficial to try to support battering fathers so they can remain in contact with their children after they divorce the children's mothers (Federico \& Kinscherff, 1996; Peled, 1996). Contact with the children may or may not involve custody. The focus of this article is whether custody should be granted and who should control decision making in the children's lives-that is, who should have legal custody of the children.

\section{Legislative Approaches}

State judges make child custody decisions based on state laws. Each state has developed its own child custody statutes. Similarly, each state has developed a method (explicitly or implicitly) for addressing domestic violence in child custody decisions.

\section{Method}

We undertook legal research to learn more about the practices of each state and the District of Columbia with regard to child custody cases involving domestic violence. We reviewed state custody laws to determine whether a pattern exists in custody cases involving domestic violence and whether and how states incorporate domestic violence into their custody statutes. Some states may include domestic violence in their visitation provisions, but this study focused only on sole and joint custody. We reviewed the most recent state custody laws and verified them through Westlaw, a legal database computer service.

\section{Findings}

States have generally adopted one of the following three approaches for addressing domestic violence in their child custody statutes: (1) rebuttable presumption statutes, which imply that it is not in a child's best interests for a batterer to have sole or joint custody of the child; (2) factor tests, which encourage judges to weigh the effects of domestic violence in determining a child's best interests, or (3) no mention of domestic violence in the statute (Table 1). These approaches are part of the best 


\begin{tabular}{|c|c|c|c|c|c|}
\hline State & $\begin{array}{c}\text { Rebuttable } \\
\text { Presumption } \\
\text { Statutes } \\
\end{array}$ & $\begin{array}{c}\text { Factor } \\
\text { Tests }\end{array}$ & $\begin{array}{c}\text { Joint Custody/ } \\
\text { Rebuttable } \\
\text { Presumption } \\
\text { Statutes } \\
\end{array}$ & $\begin{array}{c}\text { Joint Custody/ } \\
\text { Factor } \\
\text { Tests } \\
\end{array}$ & $\begin{array}{c}\text { No Mention of } \\
\text { Domestic Violence } \\
\text { in Custody Statutes }\end{array}$ \\
\hline Alabama & $\mathrm{X}$ & & $\mathrm{X}$ & & \\
\hline Alaska & & $\mathrm{x}$ & & $\mathrm{X}$ & \\
\hline Arizona $^{\mathrm{b}}$ & & $\mathrm{X}$ & $\mathrm{X}$ & & \\
\hline Arkansas & & $\mathrm{X}$ & & & \\
\hline California $a^{a, c}$ & $\mathrm{X}$ & & $\mathrm{X}$ & & \\
\hline Colorado $^{\mathrm{b}}$ & & $\mathrm{X}$ & & $\mathrm{X}$ & \\
\hline Connecticut & & & & & $\mathrm{X}$ \\
\hline Delaware $^{\mathrm{a}}$ & $\mathrm{X}$ & & $\mathrm{X}$ & & \\
\hline District of Columbia & & $\mathrm{X}$ & $\mathrm{X}$ & & \\
\hline Florida $^{\mathrm{b}}$ & & $\mathrm{X}$ & $\mathrm{X}$ & & \\
\hline Georgia & & $\mathrm{X}$ & & & \\
\hline Hawaii & $\mathrm{X}$ & & $\mathrm{X}$ & & \\
\hline Idaho & & $\mathrm{X}$ & $\mathrm{X}$ & & \\
\hline Illinois & & $\mathrm{X}$ & & $\mathrm{X}$ & \\
\hline Indiana & & $\mathrm{X}$ & & & \\
\hline Iowa $^{c}$ & & $\mathrm{X}$ & $\mathrm{X}$ & & \\
\hline Kansas & & $\mathrm{X}$ & & & \\
\hline Kentucky & & $\mathrm{X}$ & & & \\
\hline Louisiana & $\mathrm{X}$ & & $\mathrm{X}$ & & \\
\hline Maine $^{d}$ & & $\mathrm{X}$ & & $\mathrm{X}$ & \\
\hline Maryland & & $\mathrm{X}$ & & & \\
\hline Massachusetts ${ }^{\mathrm{a}}$ & $\mathrm{X}$ & & $\mathrm{X}$ & & \\
\hline Michigan & & $\mathrm{X}$ & & $\mathrm{X}$ & \\
\hline Minnesota $^{a}$ & & $\mathrm{X}$ & $\mathrm{X}$ & & \\
\hline Mississippi & & & & & $\mathrm{X}$ \\
\hline Missouri $^{\mathrm{a}}$ & & $\mathrm{X}$ & & & \\
\hline Montana & & $\mathrm{X}$ & & & \\
\hline Nebraska & & $\mathrm{X}$ & & & \\
\hline Nevada $^{a}$ & $\mathrm{X}$ & & $\mathrm{X}$ & & \\
\hline New Hampshirea & & & & $\mathrm{X}$ & \\
\hline New Jersey & & $\mathrm{X}$ & & $\mathrm{X}$ & \\
\hline New Mexico ${ }^{\mathrm{a}}$ & & & & $\mathrm{X}$ & \\
\hline New York & & $\mathrm{X}$ & & & \\
\hline North Carolina ${ }^{a}$ & & $\mathrm{X}$ & & & \\
\hline North Dakota ${ }^{a}$ & $\mathrm{X}$ & & $\mathrm{X}$ & & \\
\hline Ohio $^{a}$ & & $\mathrm{X}$ & & $\mathrm{X}$ & \\
\hline Oklahoma & $\mathrm{X}$ & & $\mathrm{X}$ & & \\
\hline Oregon & & $\mathrm{x}$ & & & \\
\hline Pennsylvania & & $\mathrm{X}$ & & & \\
\hline Rhode Island ${ }^{\mathrm{b}}$ & & $\mathrm{X}$ & & & \\
\hline South Carolina & & $\mathrm{X}$ & & & \\
\hline South Dakota & $\mathrm{X}$ & & & & \\
\hline Tennessee $^{\mathrm{a}}$ & & $\mathrm{X}$ & & & \\
\hline Texas $^{e}$ & & $\mathrm{X}$ & $\mathrm{X}$ & & \\
\hline Utah & & & & & $\mathrm{X}$ \\
\hline Vermont & & $\mathrm{X}$ & & & \\
\hline Virginia & & $\mathrm{X}$ & & & \\
\hline Washington & & $\mathrm{X}$ & & $\mathrm{X}$ & \\
\hline West Virginia & & & & & $\mathrm{X}$ \\
\hline Wisconsin & & $\mathrm{X}$ & $\mathrm{X}$ & & \\
\hline Wyoming & & $\mathrm{X}$ & $\mathrm{X}$ & & \\
\hline
\end{tabular}

NOTE: No consideration is given to whether the states require a conviction for or just allegations of domestic violence to trigger the relevant standard; how batterers' murder convictions affect the relevant standard; how visitation is determined when there is evidence of domestic violence; and how states might deal with battered women's failure to protect their children from their batterers.

${ }^{\text {aLaw }}$ requires the judge to make written findings of fact and conclusions of law.

bStatute indicates that evidence of domestic violence is contrary to the best interests of the child.

'Domestic violence should be weighed more heavily as a factor in child custody decisions.

${ }^{\mathrm{d} S}$ Statute stipulates effect of domestic violence on the award of primary residence of minor child. 
interests of the child standard and many states have created standards to encourage judges to consider domestic violence when ordering joint custody. Joint custody statutes were largely implemented in the 1980s in response to the demands of fathers who claimed that they deserved equal time with their children after the divorce

(Furstenberg, Morgan, \& Allison, 1987).

Rebuttable Presumption Statutes. Ten states have adopted rebuttable presumption statutesAlabama, California, Delaware, Hawaii, Louisiana, Massachusetts, Nevada, North Dakota, Oklahoma, and South Dakota. In these states, the law provides that it is not in the best interests of a child for an abusive parent to have sole or joint custody of the child.

Some states applying this standard also provide that it is not in the best interests of children for their abusive parents to have unsupervised visitation and that visitation arrangements must protect the safety of battered women and children (see, for example, Arizona and Hawaii in Table 1). According to these statutes, judges should assume that the nonabusive parent would better serve the best interests of the child unless the abusive parent can successfully rebut the presumption against awarding custody.

Often, abusive parents can rebut the presumption by showing that they have successfully completed a treatment program for batterers and are not abusing alcohol or illegal substances and that it is in the best interests of the child for them to have custody. States require various standards of proof to trigger and to rebut the presumption. Battered women's advocates strongly support rebuttable presumption statutes because they believe these statutes not only best protect battered women and children, but also hold batterers accountable for their abusive behavior. Fathers' rights advocates disapprove of these statutes because the statutes make it difficult for fathers to get custody of their children in cases involving domestic violence.

Factor Test Statutes. Thirty-four states and the District of Columbia have factor tests in their child custody statutes: Alaska, Arizona, Arkansas, Colorado, District of Columbia, Florida, Georgia, Idaho, Illinois, Indiana, Iowa, Kansas, Kentucky, Maine, Maryland, Michigan, Minnesota, Missouri, Montana, Nebraska, New Jersey, New York, North Carolina, Ohio, Oregon, Pennsylvania, Rhode Island, South Carolina, Tennessee, Texas,
Vermont, Virginia, Washington, Wisconsin, and Wyoming. These states take domestic violence into consideration in their child custody laws by making it "one factor" judges must consider in determining custody. States vary as to how much weight they require judges to give domestic violence as a factor in their decisions. Most states mandate that all relevant factors must be weighed equally, although some states weigh domestic violence more heavily than other factors (for example, California and Iowa). Battered women's advocates believe factor tests give judges too much discretion in terms of how much weight to accord domestic violence in their custody decisions. Fathers' rights advocates prefer factor tests because the history of domestic violence is only one of several relevant factors to be considered in the custody decision.

Relevance of Joint Custody and Other Provisions. Many states have separate joint custody provisions within their child custody laws. In most cases, these joint custody statutes supplement the general child custody statutes. In two states, New Hampshire and New Mexico, child custody is only governed by the relevant joint custody statutes. In either case, 17 states and the District of Columbia have joint custody provisions that also include rebuttable presumption provisions against awarding joint custody to batterers: Alabama, Arizona, California, Delaware, District of Columbia, Florida, Hawaii, Idaho, Iowa, Louisiana, Massachusetts, Minnesota, Nevada, North Dakota, Oklahoma, Texas, Wisconsin, and Wyoming. In addition, 10 states include domestic violence as a factor when determining whether joint custody is appropriate: Alaska, Colorado, Illinois, Maine, Michigan, New Hampshire, New Jersey, New Mexico, Ohio, and Washington.

Battered women's advocates strongly oppose joint custody because it gives batterers continued access to their victims and allows for further abuse (Cahn, 1991; U.S. Congress, 1990). They also believe that batterers have hidden motivations for seeking joint custody, such as revenge and control (Keenan, 1985). These advocates contend that when judges award batterers joint custody, children learn that violence is acceptable (Pagelow, 1990). Fathers' rights advocates support joint custody because they believe custody of children is a "right" of fatherhood and that children will benefit most from the support of both parents after divorce. 
No Mention of Domestic Violence. The four remaining states do not take domestic violence into consideration or otherwise do not accord it much weight: Connecticut, Mississippi, Utah, and West Virginia. It seems that this approach is now outdated and that most if not all states will soon mandate how judges should address domestic violence in child custody decisions.

\section{Risks of Legislative Approaches}

Recent efforts have been successful in legislating attention to domestic violence in child custody disputes. In most states, judges now take into account, to varying degrees, a history of domestic violence when making custody determinations. Our contention is that each approach has its shortcomings and that more research is necessary to help illuminate which approach best serves the needs of families affected by domestic violence.

Rebuttable presumption statutes limit judges' discretion in custody cases. Indeed, advocates have supported the rebuttable presumption approach in large part to legislate the desired outcome, namely that batterers should be denied custody of their children because where there is a history of domestic violence, the best interests of the child are undermined if the abusive parent has custody. By design, these statutes are therefore less likely to allow for a case-by-case assessment of the violent dynamic in the family.

On their face, rebuttable presumption statutes seem to solve the problem that many battered women face: that their abusive partners will either use the children as an avenue to further victimize them or to deprive them of access to their children. In addition, rebuttable presumption statutes address the problem of judicial bias by mandating the judge to presume that custody is inappropriate when one party is abusive.

Rebuttable presumption statutes, however, also have their shortcomings. For example, there has been a documented increase in arrests of women involved in domestic violence disputes (Goldberg, 1999). The District of Columbia, one of several jurisdictions experiencing this trend, reported that between 1992 and 1994, the number of women charged with assault doubled; in the same period, charges brought against men increased by less than 50 percent (Smith, 1996). Los Angeles reported even more striking results. Arrests of women increased four times over a seven-year period, from 340 women arrested in 1987 to 1,262 women arrested in 1995 (Johnson, 1996). These women were either violent themselves, retaliating for the violence they experienced at the hands of their abusive partners, or victims of a criminal justice system determined to sweep up everyone-batterer and survivor alike-who might be involved in an incident of domestic violence (Mills, 1999a). Regardless of the reason for arrest, the battered woman becomes labeled a perpetrator of a domestic violence crime, which later becomes relevant, and potentially devastating, when a family court judge applies the rebuttable presumption standard and the battered woman is denied custody on the grounds that she has a history of domestic violence.

Factor tests, on the other hand, provide judges with more latitude for deciding what custody arrangements best satisfy the children's best interests. In some families, the children may benefit from continued interaction with their abusive parents after divorce, and factor tests allow judges to consider this possibility with fewer restrictions. Factor tests allow for an individualized assessment that takes into account the complex dynamics in families with domestic violence, including the likelihood of women's violence toward their children and the tendency for their violence to subside once they separate from their abusers (Saunders, 1995).

The obvious problem with factor tests is that they involve judicial discretion and therefore raise the specter of judicial bias (Mills, 1999b). Rebuttable presumption standards address this bias by limiting the judge's discretion. The worry is that factor tests allow an otherwise unsympathetic judge to ignore the allegations of violence altogether. The requirement in some factor test states that judges prepare written findings of fact in cases involving awards to parents with violent histories addresses some of these concerns. In addition, requiring judges to weigh intimate abuse more heavily than other factors would focus the judge's attention on the effects of violence on the family.

Regardless of which of the two tests-rebuttable presumption or factor-is applied, the decision to grant joint custody may not be in the best interests of children who have been exposed to violence by one parent. Joint custody can allow the batterer to continue to exert control over the victimized parent and to expose children to abusive power dynamics and violence. Joint custody 
might be appropriate in those cases in which a batterer has reformed through treatment, and the battered parent believes that such an arrangement is appropriate.

The claim of both battered women's and fathers' rights advocates is that they are interested in safeguarding the best interests of the child. However, representatives of these respective groups focus on the parents rather than the child (Levin, 2000 ). Battered women's advocates focus primarily on battered women, not their children (Peled, 1996). Fathers' rights advocates emphasize fathers' rights to custody despite the presence of violence in the family (Fineman \& Opie, 1987; McMahon \& Pence, 1995). Neither group focuses on the children who experience domestic violence in their homes. We suggest that new research is necessary to determine which regulatory schemes (rebuttable presumption standards, factor tests, or no mention of domestic violence) best addresses the developmental, mental health, and safety interests of the children. Concern for the safety needs of battered women and the treatment concerns of batterers should also be primary goals in custody disputes involving domestic violence, especially insofar as the children will benefit enormously from our close attention to these longterm interests.

\section{References}

Aron, L. Y., \& Olson, K. K. (1997). Efforts by child welfare agencies to address domestic violence. Public Welfare, 55, 4-13.

Cahn, N. R. (1991). Civil images of battered women: The impact of domestic violence on child custody decisions. Vanderbilt Law Review, 44, 1041-1097.

Campbell, J. C., \& Lewandowski, L. A. (1997). Mental and physical health effects of intimate partner violence on women and children. Psychiatric Clinics of North America, 20, 353-374.

Carlson, B. E. (1996). Children of battered women: Research, programs and services. In A. R. Roberts (Ed.), Helping battered women: New perspectives and remedies (pp. 172-187). New York: Oxford University Press.

Coltrane, S. (1995). The future of fatherhood: Social, demographic, and economic influences on men's family involvements. In W. Marsiglio (Ed.), Fatherhood: Contemporary theory, research, and social policy (pp. 255-274). Thousand Oaks, CA: Sage Publications.

Crites, L., \& Coker, D. (1988). What therapists see that judges may miss: A unique guide to custody decisions when spouse abuse is charged. Judges' Journal, $27,9-13,40$.
Edleson, J. L. (1998). Responsible mothers and invisible men: Child protection in the case of adult domestic violence. Journal of Interpersonal Violence, $13,294-298$.

Fantuzzo, J., \& Lindquist, C. (1989). The effects of observing conjugal violence on children: A review \& analysis of research methodology. Journal of Family Violence, 4, 77-94.

Federico, P. E., \& Kinscherff, R. (1996). Custody of Vaughn: Impact of domestic violence on child custody: Children are no longer the forgotten victims. Boston Bar Journal, 40, 8-25.

Fergusson, D. M., \& Horwood, L. J. (1998). Exposure to interparental violence in childhood and psychosocial adjustment in young adulthood. Child Abuse \& Neglect, 22, 339-357.

Fineman, M. L., \& Opie, A. (1987). The uses of social science data in legal policymaking: Custody determinations at divorce. Wisconsin Law Review, 1987, 107-158.

Furstenberg, F. F., Morgan, S. P., \& Allison, P. D. (1987). Paternal participation and children's wellbeing after marital dissolution. American Sociological Review, 52, 695-701.

Gardner, R. (1992). The parental alienation syndrome: A guide for mental health and legal professionals. Cresskil, NJ: Creative Therapeutics.

Goldberg, C. (1999, November 23). Spouse abuse crackdown, surprisingly, net many women. New York Times, A16.

Hilton, N. Z. (1992). Battered women's concerns about their children witnessing wife assault. Journal of Interpersonal Violence, 7, 77-85.

Hotaling, G. T., \& Sugarman, D. B. (1990). A risk marker analysis of assaulted wives. Journal of Family Violence, 5, 1-13.

In re Heather A., 52 Cal. App. 4th 183 (1996).

Johnson, J. (1996, April 27). A new side to domestic violence: Arrests of women have risen sharply since passage of tougher laws. Critics say some men manipulate the system; Others say female abusers have long been overlooked. Los Angeles Times, A1.

Johnson, L. D. (1998). Caught in the crossfire: Examining legislative and judicial response to the forgotten victims of domestic violence. Law and Psychology Review, 22, 271-286.

Johnston, J. R., Campbell, J. R., \& Linda, E. G. (1993). Parent-child relationships in domestic violence families disputing custody. Family and Conciliation Courts Review, 31, 282-298.

Keenan, L. R. (1985). Domestic violence and custody litigation: The need for statutory reform. Hofstra Law Review, 13, 407-441.

Levin, A. B. (2000). Child witnesses of domestic violence: How should judges apply the best interests of the child standard in custody and visitation cases 
involving domestic violence? UCLA Law Review, 47, 813-857.

Liss, M. B., \& Stahly, G. B. (1993). Domestic violence and child custody. In M. Hansen \& M. Harway (Eds.), Battering and family therapy: A feminist perspective (pp. 175-187). Newbury Park, CA: Sage Publications.

McMahon, M., \& Pence, E. (1995). Doing more harm than good? Some cautions on visitation centers. In E. Peled, P. G. Jaffe, \& J. Edleson (Eds.), Ending the cycle of violence: Community responses to children of battered women (pp. 186-206). Thousand Oaks, CA: Sage Publications.

Mills, L. G. (1999a). Killing her softly: Intimate abuse and the violence of state intervention. Harvard Law Review, 113, 550-613.

Mills, L. G. (1999b). A penchant for prejudice: Unraveling bias in judicial decision making. Ann Arbor: University of Michigan Press.

O'Keefe, M. (1994a). Adjustment of children from maritally violent homes. Families in Society, 75, 403-415.

O'Keefe, M. (1994b). Linking marital violence, motherchild/father-child aggression, and child behavior problems. Journal of Family Violence, 9, 63-78.

O'Keefe, M. (1995). Predictors of child abuse in maritally violent families. Journal of Interpersonal Violence, 10, 3-25.

Pagelow, M. D. (1990). Effects of domestic violence on children and their consequences for custody and visitation agreements. Mediation Quarterly, 7, 347363.

Pagelow, M. D. (1993). Justice for victims of spouse abuse in divorce and child custody cases. Violence and Victims, 8, 69-83.

Peled, E. (1996). "Secondary" victims no more: Refocusing intervention with children. In J. L. Edleson \& Z. C. Eisikovits (Eds.), Future interventions with battered women and their families (pp. 125-153). Thousand Oaks, CA: Sage Publications.

Quirion, P., Lennett, J., Lund, K., \& Tuck, C. (1997). Protecting children exposed to domestic violence in contested custody and visitation litigation. Boston University Public Interest Law Journal, 6, 501-525.

Ross, S. M. (1996). Risk of physical abuse to children of spouse abusing parents. Child Abuse \& Neglect, 20, 589-598.

Roy, M. (1988). Children in the crossfire: Violence in the home--How does it affect our children? Deerfield Beach, FL: Health Communications.

Saunders, D. G. (1995). Prediction of wife assault. In J. C. Campbell (Ed.), Assessing dangerousness: Violence by sexual offenders, batterers, and child abusers (pp. 68-95). Thousand Oaks, CA: Sage Publications.

Smith, L. (1996, November 18). Increasingly, abuse shows female side: More women accused of domestic violence. Washington Post, p. B1.
Stark, E., \& Flitcraft, A. (1985). Woman-battering, child abuse and social heredity: What is the relationship? In N. Johnson (Ed.), Marital violence (pp. 147-171). London: Routledge \& Kegan Paul.

Straus, R. B. (1995). Supervised visitation and family violence. Family Law Quarterly, 20, 229-252.

Sun, M., \& Thomas, E. (1987). Custody litigation on behalf of battered women. New York: National Center on Women and Family Law.

Thompson, R. A. (1983). The father's case in child custody disputes: The contributions of psychological research. In M. E. Lamb \& A. Sagi (Eds.), Fatherhood and family policy (pp. 53-100). Hillsdale, NJ: Lawrence Erlbaum.

U.S. Congress. (1990). House Congressional Resolution 172: Sense of Congress respecting child custody determinations. 101st Cong., 2nd Sess. Washington, DC: U.S. Government Printing Office.

Wallerstein, J. S., \& Kelly, J. B. (1982). The father-child relationship: Changes after divorce. In S. H. Cath (Ed.), Father and child: Developmental and clinical perspectives (pp. 451-466). Boston: Little, Brown.

Wolfe, D. A., Jaffe, P., Wilson, S. K., \& Zak, L. (1988). A multivariate investigation of children's adjustment to family violence. In G. T. Hotaling, D. Finkelhor, J. T. Kirkpatrick, \& M. A. Straus (Eds.), Family abuse and its consequences: New directions in research (pp. 228-241). Newbury Park, CA: Sage Publications.

Zorza, J. (1995). How abused women can use the law to help protect their children. In E. Peled, P. Jaffe, \& J. L. Edleson (Eds.), Ending the cycle of violence: Community response to children of battered women (pp. 147-169). Thousand Oaks, CA: Sage Publications.

Amy Levin, MSW, JD, is a judicial clerk for the Honorable Richard A. Paez, United States Court of Appeals for the Ninth Circuit, 125 South Grand Avenue, Pasadena, CA 91105; e-mail: amyblevin@ yahoo.com. Linda G. Mills, JD, PhD, LCSW, is associate professor, Ehrenkranz School of Social Work; affiliated professor, School of Law; and vice provost, University Life and Interdisciplinary Initiatives, New York University.

Original manuscript received December 22, 1999

Final revision received April 20, 2001

Accepted May 16, 2001 
Copyright of Social Work is the property of National Association of Social Workers and its content may not be copied or emailed to multiple sites or posted to a listserv without the copyright holder's express written permission. However, users may print, download, or email articles for individual use. 